with each other on the basis of coordination and subordination and are endowed with broad powers in the field of environmental management within their territories.

The issue of environmental protection and rational use of nature is not a priority for the state, the state often ignores non-implementation of environmental programs at all levels and the deterioration of the environmental situation, therefore it is urgent to establish strict liability for violations of environmental legislation by government officials, which leads to mass violations of environmental human rights. And finally, corruption and abuse in the field of environmental protection, without overcoming which it is difficult to fully ensure economic security and ecological balance, to preserve the environment for posterity.

Keywords: environmental policy, state policy, principles, local authorities, waste and resource management, responsibility, sustainable development.

DOI: 10.33766/2524-0323.90.195-204

УДК 347.51(477)

Л. М. Загоруй, кандидат юридичних наук, доцент, доцент кафедри державно-правових дисциплін Луганського державного університету внутрішніх справ імені Е. О. Дідоренка

(м. Сєвєродонецьк, Україна) e-mail: mila.zh61@ukt.net

iD https:// orcid.org/0000-0002-7374-4137

\title{
ВІДШКОДУВАННЯ МОРАЛЬНОЇ ШКОДИ, ЗАВДАНОЇ НЕЗАКОННИМИ РІШЕННЯМ, ДІЯМИ (БЕЗДІЯЛЬНІСТЮ) СУДУ (СУДДІВ)
}

Автором здійснено спробу обгрунтувати запровадження в цивільному законодавстві презумпщії завдання моральної шкоди особі, яка постраждала від незаконного рішення, дії (бездіяльності) суду (суддів). Такий підхід спрямований на зміцнення базових цінностей демократичного суспільства - відповідальності держави й удосконалення інституту захисту прав, свобод та інтересів особи, розширення регулятивного потенщіалу цивільно-правової відповідальності як різновиду юридичної відповідальності. Об' єктивну необхідність потрібно шукати в площині значення юридичної відповідальності в суспільстві, iї пов' язаності з правами та свободами людини.

Ключові слова: презумпщія, моральна шкода, незаконне рішення, юридична відповідальність, цивільно-правова відповідальність суду (суддів).

Постановка проблеми. Не перший рік суспільство є свідком реформування судової влади з метою підвищення іï авторитету, довіри громадян до неї, відновлення справедливості. Вважаємо, що цей процес грунтується, з одного боку, на принципі верховенства права та неприпустимості невиправданого втручання в професійну діяльність суддів та будь-якого тиску на них. 3 іншої боку, на юридичній відповідальності суддів (дисциплінарній, адміністративній, кримінальній, цивільній), яка зумовлюється принципом рівності та недоторканності, незалежності при здійсненні правосуддя. У площині зазначеного однією із теоретичних проблем, яка не

(C) Загоруй Л. М., 2020 
має однозначного висвітлення в юридичній літературі, $є$ цивільно-правова відповідальність суду (судів) та відшкодування потерпілому моральної шкоди.

Питання про неналежну якість здійснення правосуддя, що спричиняє матеріальну та моральну шкоду, залишаються актуальними, оскільки вони пов' язані із відновленням справедливості в межах цивільно-правової відповідальності та грунтуються на принципі рівності в межах юридичної відповідальності. Наявність завданої моральної шкоди потерпілому також свідчить про недосконалість засобів протидії незаконним рішенням, діям (бездіяльності) суду (судді) й необхідності проводжувати пошуки ефективних протидій.

Аналіз останніх досліджень і публікацій. Притягнення суддів до юридичної відповідальності, у тому числі цивільно-правової, та відшкодування шкоди є предметом дослідження таких науковців, як: І. В. Бурлака, А. О. Нємцева, Г. Л. Пендяга, Н. В. Терещенко, О. М. Овчаренко, С. В. Подкопаєв, Л. М. Москвич, Л. С. Виноградова, Л.В.Мелех, О.В.Гончаренко, В. П. Присяжнюк, Л. В. Бєлая та ін. Авторами досліджені передумови відшкодування шкоди, завданої суддею (умисел судді на порушення законодавства), загальні засади цивільно-правової відповідальності судді, за наявності яких тягар відповідальності покладено на державу. Викликає науковий інтерес таке питання: чи є обов'язок відшкодування шкоди, завданої без вини, цивільно-правовою відповідальністю, чи це міра захисту? Дискусійним залишається питання про цивільно-правову відповідальність суду (суддів, судді), оскільки це взаємопов' язано з імунітетом, незалежністю судді.

Формулювання цілей. На підставі аналізу наукових джерел та чинного цивільного законодавства обгрунтовується доцільність впровадження презумпщії завдання моральної шкоди особі, яка постраждала від незаконного рішення, дії (бездіяльності) суду (судді) для підсилення принципу рівності в питаннях цивільноправової відповідальності.

Виклад основного матеріалу. Становлення інституту відшкодування шкоди, завданої незаконними рішеннями, діями чи бездіяльністю суду (судді) тривало поступово. Історія питання починається від приватної відповідальності суддів в стародавні часи за умови наявності в їх діях (бездіяльності) вини та безвідповідальності держави за шкоду, завдану посадовими особами, яка залишалась незмінною майже до XVIII століття. Однак уже до кінщя вказаного століття ідея відшкодування державою шкоди, завданої владою, отримала суспільне визнання, як зазначає М. О. Розин, та знайшла підтримку в багатьох європейських країнах [1, с. 6]. У першу чергу було вирішено питання щодо компенсації витрат та страждань особі, до якої застосували кримінальне переслідування за відсутності вини як потерпілого, так і тих, хто переслідував [1, с. 6]. Науковці вважають, що першою державою, яка включила до законодавства положення про матеріальне відшкодування потерпілому, була Пруссія (1766 рік) [1, с. 10]. Законодавство Російської імперії того часу передбачало особисту відповідальність суддів, прокурорів за наявності в їхніх діях користі або злого умислу.

До початку XX ст. у всіх європейських державах інститут відповідальності держави за шкоду, заподіяну посадовими та службовими особами поширився на сферу правосуддя та адміністративного управління. Тривалий шлях формування 
зазначеної відповідальності, на думку М. О. Розина, був зумовлений необхідністю осмислення юридичної природи відповідальності держави [1, с. 24].

Отже, як результат еволюційного процесу формування, у діючому законодавстві України закріплена складна цивільно-правова конструкція відповідальності держави незалежно від вини посадових та службових осіб органу, що здійснює оперативно-розшукову діяльність, досудове розслідування, прокуратури або суду (ст. 1176 ЦК України). Підгрунтям цього процесу є потреба в запровадженні гарантій щодо захисту прав та інтересів потерпілого від свавілля, зловживання осіб, які беруть на себе обов'язок (як прояв публічної влади) вирішувати проблемні питання, притягувати до відповідальності тощо.

Зміст статті 1176 ЦК України підтверджує встановлення різних правових режимів відповідальності держави в разі незаконного притягнення до кримінальної або адміністративної відповідальності посадовими та службовими особами органу, що здійснює оперативно-розшукову діяльність, досудове розслідування, прокуратури або суду, та відшкодування шкоди, завданої фізичній або юридичній особі внаслідок постановлення судом незаконного рішення в цивільній справі. Правовий режим - це особливий порядок правового регулювання певної сфери суспільних відносин [2, с. 143]. 3 урахуванням зазначеного, відповідно до ч. 1 ст. 1176 ЦК України, шкода, завдана фізичній особі внаслідок незаконних дій, пов' язаних із притягненням до кримінальної або адміністративної відповідальності, відшкодовується державою в повному обсязі незалежно від вини посадових та службових осіб. Це підвищена відповідальність держави, яка грунтується на ст. 56 Конституції України, де закріплено, що «кожен має право на відшкодування за рахунок держави чи органів місцевого самоврядування матеріальної та моральної шкоди, завданої незаконними рішеннями, діями чи бездіяльністю органів державної влади, органів місцевого самоврядування, їх посадових і службових осіб при здійсненні ними своїх повноважень» та ч. 4 ст. 62 Конституції України, у якій передбачено, що «... у разі скасування вироку суду як неправосудного держава віпшкодовує матеріальну і моральну шкоду, завдану безпідставним засудженням» [3].

Чинне законодавство передбачає порядок відшкодування моральної шкоди завданої судом. Зазначимо: це п. 2 ч. 2 ст. 1167 ЦК України, ст. 11-13 Закону України «Про порядок відшкодування шкоди, завданої громадянинові незаконними діями органів, що здійснюють оперативно-розшукову діяльність, органів досудового розслідування, прокуратури і суду» (далі - Закон) [4], Положення про застосування Закону України «Про порядок відшкодування шкоди, завданої громадянинові незаконними діями органів дізнання, попереднього слідства, прокуратури і суду», затверджене наказом Міністерства юстиції, Генеральної прокуратури та Міністерства фінансів України від 04.03.1996 р. № 6/5/3/41 (далі - Положення) [5]. Встановлені вичерпні підстави для відшкодування моральної шкоди та виключно судовий порядок вирішення цього питання (ст. 13 Закону, п. 17 Положення). Однак базовим підходом законодавця є відсутність визнання презумпції завдання моральної шкоди реабілітованій особі. Відповідно до ч. 5 ст. 4 Закону, моральна шкода підлягає відшкодуванню, коли незаконні дії, у тому числі суду, завдали моральної втрати громадянинові, призвели до порушення його нормальних життєвих зв' язків, вимагають від нього додаткових зусиль для організації свого життя [4]. Таким чином, позитивним 
$€$ те, що передбачено відшкодування моральної шкоди, але потерпілий повинен доказувати завдання йому моральної шкоди. Навіть більше, процедура відшкодування може бути ускладнена призначенням експертизи, якщо для з' ясування обставин щодо наявності в громадянина моральної шкоди виявиться потреба в спеціальних знаннях (п.17 Положення) [5]. Висновок оцінюється судом поряд з іншими доказами в справі. У разі недоведеності спричинення моральної шкоди йому буде відмовлено в задоволенні заявлених вимог. Виникає питання, наскільки це справедливо (тут і далі курсив автора - Л. 3.) по відношенню до постраждалої сторони (виправданої, реабілітованої)? По-перше, діяльність правоохоронних органів, суду об'єктивно може мати «негативний» характер в тому плані, що до того, як буде остаточно вирішена справа по суті щодо винності людини, до неї можуть бути застосовані, наприклад, кримінально-процесуальні, цивільно-процесуальні заходи. По-друге, сам факт вчинення незаконних дій, рішення (бездіяльності) підтверджується відповідними документами (виправдувальним вироком суду, рішенням суду тощо). Навіть більше, тільки за наявності реабілітуючих документів виникає право на відшкодування шкоди в розмірах і в порядку, передбачених вищевказаним законом (ст. 2 Закону). По-третє, відповідальність без вини для потерпілого - це шлях до нематеріальних (душевних) страждань, які підривають віру $b$ справедливість, у закон, оскільки несправедливим є ухвалення незаконного рішення, вчинення незаконної дії тощо. Така відповідальність впливає на правосвідомість потерпілого, на повагу до суду та інших державних органів.

На нашу думку, з урахуванням змісту ч. 1 ст. 1176 ЦК України та положень вказаного Закону, було б справедливим виходити 3 презумпщії завдання моральної шкоди особі (потерпілому) та перекладання обов' язку спростовувати зворотне на відповідача - це Держава Україна в особі Державної казначейської служби України. По-перше, такий підхід розподіляє тягар доказування між сторонами, оскільки вказується, хто та яким чином може оспорювати певний факт. По-друге, у цілому це сприятиме більш ефективному розгляду спірного питання та прийняттю законного, обгрунтованого рішення щодо відшкодування моральної шкоди. Нарешті через інститут відповідальності держави законодавець вимагає належного виконання своїх позитивних зобов' язань.

Запровадження презумпції завдання моральної шкоди потерпілому, можливо, вплине і на зменшення кількості оскаржень рішень щодо відшкодування моральної шкоди. Зокрема, рішенням міськрайонного суду у 2016 році задоволено позов про відшкодування моральної шкоди в розмірі 50 тис. грн. у зв'язку із незаконним кримінальним переслідуванням (Апеляційний суд Івано-Франківської області у справі № 346/4623/15-ц) [6]. На вказане рішення була подана апеляційна скарга, у якій обгрунтовувалась відсутність у позивача права на відшкодування моральної шкоди з підстав, передбачених ч. 1 ст. 1176 ЦК України, оскільки позивач, на думку апелянта, повинен був довести сам факт завдання йому моральної шкоди, але це не було доведено позивачем, тому не можна зробити висновок про наявність моральної шкоди. Суд апеляційної інстанції відмовив у задоволенні апеляційної скарги. Позивач посилався на те, що, внаслідок незаконного кримінального переслідування, йому завдана моральна шкода (протилежне не було доведено), а розмір шкоди він обгрунтував належним чином [6]. 
У справі № 6-1435 від 27 вересня 2017 року Верховний Суд звернув увагу на те, що в деліктних зобов' язаннях саме на відповідача покладено обов'язок спростування презумпщії вини шляхом доведення відсутності його вини в завданні шкоди позивачу. Суди мали б виходити з презумпщії спричинення позивачу моральної шкоди відповідачем та обов' язку саме відповідача спростувати таку презумпцію [7].

Наведені приклади свідчать про те, що суд, встановивши факт вчинення незаконного рішення, дії (бездіяльності), вважає що моральна шкода завдана потерпілому і підлягає відшкодуванню.

Далі слід зазначити, що ст. 56 Конституції України майже не працює, коли йдеться про відшкодування шкоди, завданої фізичній або юридичній особі внаслідок постановлення судом незаконного рішення в цивільній справі - ч. 5 ст. 1176 ЦК України, оскільки держава відшкодовує в повному обсязі в разі встановлення в діях судді (суддів), які вплинули на постановлення незаконного рішення, складу злочину за обвинувальним вироком суду, що набрав законної сили. Ця новела діючого законодавства, у порівнянні зі змістом статті 443 ЦК УРСР 1963 року, свідчить про удосконалення механізму захисту прав та інтересів особи при відшкодуванні завданої шкоди. Водночас цивільно-правова відповідальність держави обумовлена кримінальною відповідальністю суддів, тобто є обмеженою в порівнянні 3 відповідальністю держави, яка встановлена в ч. 1 ст. 1176 ЦК України. У Кримінальному кодексі України передбачена відповідальність суддів за злочини проти правосуддя, у тому числі за постановлення суддею (суддями) завідомо неправосудного вироку, рішення, ухвали або постанови (ст. 375 КК України). Зазначене викликає практичний інтерес суддів, прокурорів, адвокатів, у тому числі й науковців, оскільки, з одного боку - це можливість тиску на суддів з різних причин, а $з$ іншого - притягнення до кримінальної відповідальності за незаконне рішення. Звичайно, кримінальна відповідальність суддів не може наставати за будь-яке незаконне рішення, оскільки подібні помилки виправляються в апеляційному та касаційному провадженнях. Визначальною в питаннях кримінальної відповідальності, зазначає Венеціанська комісія (2017р.), є встановлення особистої вини у формі умислу («malice») або необережності, що досягла порогу «gross negligence» [8].

Вважаємо, що в діючій редакції частина 5 статті 1176 ЦК України суперечить ст. 56 Конституції України, у якій немає додаткових умов для відшкодування шкоди за рахунок держави, окрім визнання рішення, дії чи бездіяльності вказаних органів, їх посадових і службових осіб, незаконним. Суперечність національної норми можна виявити порівнюючи іï з міжнародними документами, зокрема у п. 5.2 Європейської хартії про закон «Про статус суддів» проголошено, що «... компенсация за ущерб, понесенный неправомерно в результате решения или поведения судьи при исполнении им своих обязанностей, гарантируется государством. В Законе может быть предусмотрено право государства потребовать от судьи в судебном порядке возмещения таких расходов, но не больше установленных размеров, в случае грубого и непростительного нарушения правил, регулирующих исполнение судейских обязанностей» [9]. Отже, якщо країна прагне наблизити національне законодавство до європейських стандартів і дотримуватись верховенства права, вважаємо за необхідне елімінувати виявлені неузгодженості. Проблема 
потребує свого розв'язання, і фахівці на це звертають увагу. Деякі шляхи ії вирішення можна знайти в наукових працях, зокрема, Л. С. Виноградова пропонує передбачити в ЦК України обов' язковість відшкодування державою матеріальної і моральної шкоди, завданої фізичним і юридичним особам, винесенням і виконанням незаконних і необгрунтованих судових рішень; притягнення за це винних до матеріальної відповідальності в порядку регресу в повному чи обмеженому розмірі залежно від характеру вини [10, с. 5]. Позищія вченої є слушною.

Загалом ідея законодавця, закріплена в статті 1176 ЦК України, є зрозумілою удосконалення механізму захисту прав, свобод та законних інтересів потерпілої особи, підвищення відповідальності, у тому числі, при здійсненні правосуддя в разі незаконного притягнення до кримінальної та адміністративної відповідальності. Однак способи досягнення вказаної мети не повинні ускладнювати шляхи до захисту осіб, які постраждали від незаконних дій (бездіяльності), незаконного рішення.

На нашу думку, постановлення судом незаконного рішення в цивільній справі спрямовано на порушення прав, свобод та законних інтересів особи. Оцінка незаконності рішення суду є компетенщією вищестоящих судів (наприклад, ст. 376 ЦПК України), що спрямовано, як слушно вказує О. М. Овчаренко, на захист суддівського розсуду [11, с. 7]. Зазначене можна проілюструвати статистичними покажчиками, зокрема, на підставі огляду даних про стан здійснення правосуддя у сфері цивільного судочинства 2018 року. Кількість скасованих та змінених рішень, ухвал місцевих судів, відповідно до кількості ухвалених рішень (ухвал), становить лише 3,5 відсотки (у 2017 р. - 4, 1 відсотка) [12]. Статистика свідчать про тенденщію підвищення рівня розгляду цивільних справ, оскільки зменшується кількість скасованих та змінених рішень, але в цілому такі рішення є. Вважаємо, якщо оцінка рішення відбулася, тобто встановлена його незаконність, то виникають підстави для відшкодування завданої моральної шкоди. Сторона, яка потерпіла від незаконного рішення судді (суддів), по-перше, перебуває в стресовому стані, морально страждає, можливо, не впевнена щодо своїх прав та законних інтересів; по-друге, втрачається довіра на справедливий суд, і потрібно докладати додаткові (інколи суттєві) моральні та фінансові (оплата послуг адвоката, призначення експертиз тощо) зусилля для скасування незаконного рішення суду, що побічно створює перешкоди в доступі до правосуддя. Отже, з метою підвищення ефективності захисту прав та інтересів потерпілої особи, пропонуємо поширити презумпцію завдання моральної шкоди особі, яка постраждала від незаконного рішення, дій (бездіяльності) судді (суддів) також на сферу цивільних справ (ч. 5 ст. 1176 ЦК України). Ми підтримуємо позицію тих авторів, які доказують необхідність захисту вирішувати питання відшкодування моральної шкоди в такий спосіб. Утім існують різні підходи до застосування зазначеної презумпщії. Зокрема О. І. Панченко, досліджуючи цивільно-правову відповідальність поліцейських в Україні, доказує доцільність закріплення на законодавчому рівні презумпції завдання моральної шкоди особі, яка постраждала від незаконних діянь поліцейських [13]. Такий підхід, на нашу думку, є обгрунтованим, але ми пропонуємо його розширити, а саме, закріпити в чинному цивільному законодавстві презумпщію завдання моральної шкоди особі, яка постраждала від незаконного рішення, дії чи 
бездіяльності суду (суддів). У даному випадку беремо за основу те, що держава повинна вважати, що потерпілий морально страждає, якщо інше не буде доведено. Моральна шкода завдана самим фактом прийняття незаконного рішення, дії (бездіяльності) суду (судді). Особа не повинна підтверджувати факт моральних страждань, а має надати обгрунтування розміру відшкодування моральної шкоди та те, якими доказами це підтверджується. Подібний підхід ми можемо знайти в рішеннях Європейського суду з прав людини (далі - ЄСПЛ), де суд виходить із презумпщії спричинення моральної шкоди позивачу відповідачем та обов'язку відповідача спростувати таку презумпцію. ЄСПЛ застосовує у своїх рішеннях «... так звану «презумпцію заподіяння немайнових витрат», яка може бути спростована іншою стороною» [14, с. 260].

На підставі зазначеного та з урахуванням єдиного підходу в діючому цивільному законодавстві відшкодування моральної шкоди, завданої як судом, так й органу, що здійснює оперативно-розшукову діяльність, досудове розслідування, прокуратури, пропонуємо презумпцію завдання моральної шкоди особі, яка постраждала від незаконного рішення, дії чи бездіяльності суду (суддів), поширити також на незаконні рішення, дії чи бездіяльність вказаних органів та прокуратуру.

Висновки. Запровадження презумпщії завдання моральної шкоди фізичній або юридичній особі внаслідок постановлення судом незаконного рішення в цивільній справі (ч. 5 ст. 1176 ЦК України) та застосуванні ї̈ в разі незаконних рішень, дії чи бездіяльності органу, що здійснює оперативно-розшукову діяльність, досудове розслідування, прокурати або суду (ч. 1 ст. 1176 ЦК України) спрямовано на зміцнення базових цінностей демократичного суспільства, зокрема відповідальність держави й удосконалення інституту захисту прав, свобод та інтересів особи. Зазначене фіксує конкретний варіант поведінки, якого повинні дотримуватись сторони, коли вони опинилися в певній юридичній ситуації, а наукова та практична доцільність полягає в розширенні регулятивного потенщіалу цивільно-правової відповідальності як різновиду юридичної відповідальності. Об'єктивну необхідність потрібно шукати в площині значення юридичної відповідальності в суспільстві, ï пов'язаності з правами та свободами людини.

\section{Використані джерела:}

1. Розин Н. О. О вознаграждении лищ, невинно привлеченных к уголовному суду. URL: https:/ / books.google.com.ua/ (дата звернення: 14.03.2020).

2. Теорія держави і права: підручник / О. В. Петришин, С. П. Погребняк, В. С. Смородинський та ін.; за ред. О. В. Петришина. Харків: Право, 2015. 368с.

3. Конституція України: чинне законодавство зі змінами та допов. станом на 2 січ. 2019 p. URL: https:/ / zakon.rada. gov.ua/laws/show/254\%D0\%BA/96-\%D0\%B2\%D1\%80 (дата звернення: 20.03.2020).

4. Про порядок відшкодування шкоди, завданої громадянинові незаконними діями органів, що здійснюють оперативно-розшукову діяльність, органів досудового розслідування, прокуратури і суду: Закон України від 1 грудня 1994 р. № 266/94-BP. URL: https:/ / zakon.rada.gov.ua/laws/show/266/94-\%D0\%B2\%D1\%80 (дата звернення: 16.03.2020).

5. Про затвердження Положення про застосування Закону України «Про порядок відшкодування шкоди, завданої громадянинові незаконними діями органів дізнання, по- 
переднього слідства, прокуратури і суду» : Наказ Міністерства юстиції, Генеральної прокуратури та Міністерства фінансів від 04.03 .1996 р. № 6/5/3/41, поточна редакція від 03.04.1998 p. URL: https:/ / zakon.rada. gov.ua/laws/show/ru/z0106-96\#о13 (дата звернення: 10.03.2020).

6. Апеляційний суд Івано-Франківської області у справі №346/4623/15-ц. Протокол. Юридичний інтернет ресурс. URL: https://protocol.ua/ua/ sud_50_tis_moralnoi_shkodi_ za_trivale_bezpidstavne_zvinuvachennya/ (дата звернення: 14.03.2020).

7. Судова влада: Апеляційний суд Одеської області. URL: https:// oda.court. gov.ua/ sud1590/pravovipoziciivsu/6-1435cs17 (дата звернення: 10.03.2020).

8. Венеціанська комісія сформулювала необхідні умови для притягнення суддів для кримінальної відповідальності. URL: https://zib.com.ua/ua/128019-venecianska_komisiya_ sformulyuvala_neobhidni_umovi_dlya_prit.html (дата звернення: 10.03.2020).

9. Свропейська хартія про закон «Про статус суддів» від 10.07.1998 p. № 994_236. URL: https:// zakon.rada.gov.ua/ laws/show/994_236 (дата звернення: 20.03.2020).

10. Виноградова Л. Є. Юридична відповідальність суддів загальних судів України: автореф. дис. ... канд. юрид. наук : 12.00.10. Одеса, 2004. 18 с. URL: https:// dspace.onua. edu> handle (дата звернення: 20.03.2020).

11. Овчаренко О. М. Юридична відповідальність суддів: питання теорії і практики. Одеса, 2018. URL: https://dspace.onua.edu.ua >bitstream>handle> Diss_Jvcharenko (дата звернення: 20.03.2020).

12. Огляд даних про стан здійснення правосуддя у 2018 рощі. Сайт Судова влада України. URL: https:// court.gov.ua/ inshe/sudova_statystyka/analit_rewiew_18 (дата звернення: 20.03.2020).

13. Панченко О. І. Цивільно-правова відповідальність поліцейських в Україні: автоpeф. дис. ...канд. юрид. наук: 12.00.03. Київ. 2019. 22 с. URL: http://elar.naiau.kiev.ua/ bitstream/ 123456789/14535/1/avtoreferat_panchenko_oi.pdf (дата звернення: 16.03.2020).

14. Примак В. Д. Віпшкодування моральної шкоди у рішеннях Європейського суду 3 прав людини: орієнтири для вітчизняного законодавця і судової практики. Серія Право. Випуск 23. Частина 1. Том 1. С. 258-262. URL: https:// dspace.uzhnu.edu.ua/ jspui/ bitstream/ lib/6692/1/pdf (дата звернення: 07.03.2019).

\section{References:}

1. Rozin, N. O. O voznagrazhdenii lits, nevinno privlechennyih k ugolovnomu sudu. N. d. N. p. URL: https://books.google.com.ua/ [in Ukrainian].

2. Teoriya derzhavi i prava : pidruchnik (2015). O. V. Petrishin, S. P. Pogrebnyak, V. S. Smorodinskiy (Eds.) et al.; O. V. Petrishin (Ed.). Harkiv: Pravo. [in Ukrainian].

3. Konstitutsiya Ukrayini: chinne zakonodavstvo zi zminami ta dopov. stanom na 2 sich. 2019 r. N. p. URL: https:// zakon.rada.gov.ua/laws/show/254\%D0\%BA/96-\%D0\% B2\% D1\%80 [in Ukrainian].

4. Pro poryadok vidshkoduvannya shkodi, zavdanoyi gromadyaninovi nezakonnimi diyami organiv, scho zdiysnyuyut operativno-rozshukovu diyalnist, organiv dosudovogo rozsliduvannya, prokuraturi i sudu: Zakon Ukrayini vid 1 grudnya 1994 r. \# 266/94-VR. N. p. URL:https:/ / zakon.rada.gov.ua/laws/show/266/94-vr. [in Ukrainian].

5. Pro zatverdzhennya Polozhennya pro zastosuvannya Zakonu Ukrayini «Pro poryadok vidshkoduvannya shkodi, zavdanoyi gromadyaninovi nezakonnimi diyami organiv diznannya, poperednogo slidstva, prokuraturi i sudu»: Nakaz Ministerstva yustitsiyi, Generalnoyi prokuraturi ta Ministerstva finansiv vid 04.03.1996 r. \# 6/5/3/41, potochna redaktsilya vid 03.04.1998 r. (1998) N. p. URL: https:// zakon.rada.gov.ua/ laws/show/ru/ z0106-96\#o13. [in Ukrainian]. 
6. Apelyatsiyniy sud Ivano-Frankivskoyi oblasti u spravi \#346/4623/15-ts. Protokol. Yuridichniy Internet resurs. N. d. N. p. URL: https:// protocol.ua/ua/ sud_50_tis_moralnoi_ shkodi_za_trivale_bezpidstavne_zvinuvachennya/. [in Ukrainian].

7. Sudova vlada: Apelyatsilyniy sud Odeskoyi oblasti.N. d. N. p. URL: https:// oda.court. gov.ua/sud1590/pravovipoziciivsu/6-1435cs17.[in Ukrainian].

8. Venetsianska komisiya sformulyuvala neobhidni umovi dlya prityagnennya suddiv dlya kriminalnoyi vidpovidalnosti. N. d. N. p. URL: https://zib.com.ua/ua/128019-venecianska_ komisiya_sformulyuvala_neobhidni_umovi_dlya_prit.html. [in Ukrainian].

9. Evropeyska hartiya pro zakon «Pro status suddiv» vid 10.07.1998 r. \# 994_236. N. p. URL: https:// zakon.rada. gov.ua/laws/show/994_236. [in Ukrainian].

10. Vinogradova, L. E. (2004). Yuridichna vidpovidalnist suddiv zagalnih sudiv Ukrayini. Extended adstract of candidate's thesis. Odesa. URL: https:// dspace.onua.edu>handle. [in Ukrainian].

11. Ovcharenko, O. M. (2018). Yuridichna vidpovidalnIst suddiv: pitannya teoriyi i praktiki. Odesa. URL: https:// dspace.onua.edu.ua >bitstream>handle>Diss_Jvcharenko. [in Ukrainian].

12. Oglyad danih pro stan zdiysnennya pravosuddya u 2018 rotsi. Sayt Sudova vlada Ukrayini. N. p. URL: https:// court.gov.ua/inshe/sudova_statystyka/analit_rewiew_18. [in Ukrainian].

13. Panchenko, O. I. (2019). Tsivilno-pravova vidpovidalnist politseyskih v Ukrayini. Extended adstract of candidate's thesis. Kyiv. URL: http:/ / elar.naiau.kiev.ua/ bitstream/ 123456789/ 14535/1/ avtoreferat_panchenko_oi.pdf. [in Ukrainian].

14. Primak, V. D. Vidshkoduvannya moralnoyi shkodi u rishennyah Evropeyskogo sudu z prav lyudini: orientiri dlya vitchiznyanogo zakonodavtsya i sudovoyi praktiki. Seriya Pravo - The Right Series, issue 23, art. 1, Vol. 1, 258-262. URL: https:/ / dspace.uzhnu. edu.ua/jspui/ bitstream/ lib/6692/1/pdf. [in Ukrainian].

Стаття надіӥшла до редколегї 12.06.2020

Загоруй Л. Н., кандидат юридических наук, доцент, доцент кафедры государственно-правовых дисциплин Луганского государственного университета внутренних дел имени Э. А. Дидоренко (г. Северодонецк, Украина)

\section{ВОЗМЕЩЕНИЕ МОРАЛЬНОГО ВРЕДА, ПРИЧИНЕННОГО НЕЗАКОННЫМИ РЕШЕНИЯМИ, ДЕЙСТВИЯМИ (БЕЗДЕЙСТВИЯМИ) СУДА (СУДЕЙ)}

Автором предпринята попытка обосновать введение презумпци причинения морального вреда потерпевшему в гражданское законодательство, причиненного незаконными решениями, действиями (бездействиями) суда (судей). Такой подход направлен на укрепление базовых ценностей демократического общества - ответственности государства и усовершенствование института защиты прав, свобод и интересов лица, а также расширение регулятивного потенциала гражданско-правовой ответственности как разновидности юридической ответственности. Объективную необходимость следует искать в значении юридической ответственности в обществе, её связанности с правами и свободами человека. 
Ключевые слова: презумпция, моральный вред, незаконное решение, юридическая ответственность, гражданско-правовая ответственность суда (судей).

\author{
Zagoruy L., \\ Candidate of Law, Associate Professor, \\ Associate Professor of the Department \\ of State Law Disciplines of the \\ Luhansk State University of Internal Affairs \\ named after E. Didorenko \\ (Sievierodonetsk, Ukraine)
}

\title{
COMPENSATION FOR MORAL DAMAGE CAUSED BY UNLAWFUL DECISIONS, ACTIONS (INACTION) OF THE COURT (JUDGES)
}

The author notes that for several years the society has witnessed the reform of the judicial power in order to increase its authority, citizens' trust in it and to restore justice. In the plane of this, one of the theoretical problems, which do not have unambiguous coverage, is the civil and legal liability of the court (judges) and compensation of moral damage to the victim. The issue of the inadequate quality of the administration of justice, that causes material and moral damage, remains urgent because they are associated with the restoration of justice in the framework of civil and legal liability and are based on the principle of equality within the limits of legal responsibility.

Availability of victim's moral harm also indicates the imperfection of means of counteracting unlawful decisions, actions (inactions of the court, the judge) and the need to continue searching ways for effective counteractions.

Based on the analysis of scientific sources and the current civil legislation, the expediency of introducing the presumption of moral damage to a person caused by illegal decisions, actions (inaction) of the court (judge) to reinforce the principle of equality in matters of civil liability is substantiated.

Taking into account the unified approach in civil legislation to compensate moral damage caused by both the court and the body carrying out operational investigative activities, pre-trial investigation, prosecutor's office, the presumption of moral damage caused to the person by illegal decisions, actions or omission of the court (judges), expansion of actions or inaction of these bodies and the prosecutor's office on illegal decisions is proposed. This approach is, firstly, aimed at strengthening the basic values of the democratic society, responsibility and improvement of the institution of protecting human rights, freedoms and person's interests. Secondly, a specific variant of behavior is fixed which the parties must adhere to when they find themselves in a certain legal situation. Scientific and practical expediency is to expand the regulatory potential of civil and legal liability as a form of juridical responsibility. Objective necessity must be sought in the plane of the meaning of juridical responsibility in the society, its connection with human rights and freedoms.

Keywords: presumption, moral damage, illegal decision, legal liability, civil and legal liability of the court (judges). 